\title{
Foreword - The crisis, ten years after: Lessons learnt for monetary and financial research
}

\author{
Andreas Beyer*, Benoît Cœuré*, Caterina Mendicino*
}

\begin{abstract}
Ten years after the global and European financial crises, significant progress has been made both in financial and economic research to address the shortcomings of mainstream modelling frameworks used to inform monetary and financial policymaking. This article first reviews the progress made in the field of econometric modelling, namely more elaborated financial sectors, partial non-linearity, addressing the effective lower bound for interest rates, and dealing with heterogeneity across countries and economic agents. We then describe how such progress has helped assessing the impact of unconventional monetary policy and the interaction between monetary and prudential policies, also building on the extensive use of micro-data. We conclude that more research remains needed on the transmission of negative rates and their financial stability repercussions, and to understand better central bank communication (including forward guidance on monetary policy) by introducing elements of bounded rationality. Research remains also needed on building models with more heterogeneous agents, given the relevance of heterogeneity for the transmission of monetary policy and the rising importance of inequality in the broader policy discussion.
\end{abstract}

JEL Classification: E4, E5, G1, G2

Keywords: financial crisis, macroeconomic modelling, unconventional monetary policy, macroprudential policy, banking supervision

Reminder:

The opinions and analyses in this article

are those of the author(s)

and do not

necessarily reflect

their institution's

or Insee's views.
*European Central Bank (Andreas.Beyer@ecb.europa.eu; Benoit.Coeure@ecb.europa.eu; Caterina.Mendicino1@ecb.europa.eu). Acknowledgments: This article has benefited from comments and suggestions made by Carlo Altavilla, Matthieu Darracq Pariès, Florian Heider, Geoff Kenny, Ana Lamo, Luc Laeven, Simone Manganelli, Michael Ehrmann, Sandra Gomes, Michele Lenza, David Marqués, Alex Popov, Sebastian Schmidt, Jirka Slačálek and Frank Smets. 


\section{Introduction}

Ten years after the beginning of the Great Financial Crisis, the repercussions of the economic and financial fallout are still being felt. Bold and unprecedented action by public authorities, accompanied by progress in the institutional and regulatory financial architecture, have, however, helped to reduce economic slack, to bring down record unemployment and to put the world economy and the euro area, at last, back on a path of solid economic expansion.

These successes would not have been possible without a considerable rethink of the interactions between the financial and real economy, the workings of unconventional monetary policy measures at, or close to, the effective lower bound, and the importance of sound regulatory and supervisory policies. The global and euro area crises exposed significant shortcomings in the mainstream modelling frameworks used at central banks to analyse and forecast economic and inflationary trends, in particular the absence of a financial sector as a possible source or amplifier of economic shocks (see Cœuré, 2012, for an earlier discussion of the post-crisis modelling agenda). Many models today feature a fully fledged banking sector that accounts for the presence of financial frictions and that also allows the effects of macroprudential policies to be analysed (that is, policies aimed at safeguarding the stability of the overall financial system). Similarly, the short-term interest rate that used to summarise the monetary policy stance in macroeconometric models needed to be replaced with a more elaborate exposition of the monetary transmission mechanism, including the role of public and private balance sheets. This allows the transmission channels of central bank asset purchase programmes and the effects of such measures on financial asset prices and the broader economy to be fully understood.

This foreword takes a central bank perspective on progress made in monetary and financial research, drawing in particular (but not only) on research undertaken at the European Central Bank (ECB). It does not touch upon all areas relevant to central bank policies. For example, debate is still raging among economists on the appropriate balance between fiscal stabilisation and fiscal sustainability in recessions (including on the size of fiscal multipliers), on the shortcomings of real and nominal adjustment mechanisms in Europe's economic and monetary union and on the design of more efficient risk-sharing arrangements. Another topic that has received considerable attention since the crisis is the causes of low inflation. Over the past few years, inflation has been persistently low across many developed countries despite a sizeable reduction in economic and labour market slack. This has brought back into the spotlight a discussion on the shape, specification and location of the Phillips-curve as well as on the role of broad financial conditions in stimulating economic growth and, ultimately, inflation: see Kuttner and Robinson (2010), Ball and Mazumder (2011), and the collection of articles edited by Ciccarelli and Osbat (2017). Notwithstanding their importance, these questions will not be addressed in this article.

The section 2 of this foreword reviews the advances in econometric modelling stimulated by the recent crisis, while section 3 discusses the analysis of the impact of non-standard monetary policy measures. Section 4 takes stock of the recent contributions made to the literature on the interactions between macroprudential and monetary policies, focusing on the euro area. Finally, the conclusions include suggestions for future research. 


\section{Challenges for Pre-crisis Macroeconometric Models}

Before the outbreak of the Great Financial Crisis, the vast majority of models developed within national administrations, international organisations and central banks had increasingly been derived from first principles, with rational and forward-looking households and firms, building on the seminal contributions of Christiano et al. (2005) and Smets and Wouters (2007). The theoretical foundations of such dynamic stochastic general equilibrium (DSGE) models and their quantitative assessment offered policymakers an internally consistent framework for a structural interpretation of alternative monetary and fiscal policy scenarios. State-of-the-art macroeconometric models took into account nominal price and wage rigidities and real rigidities in consumption and investment, and incorporated a Taylor-type interest rate rule for the conduct of monetary policy. Most models featured a detailed fiscal sector and, in some cases, they took into account financially constrained households whose consumption was driven by their current income rather than by lifetime optimisation. Despite differences in the degree of micro-foundation, the estimation period and the country of reference, there was a significant convergence in international organisations and the global central banking community in the qualitative and quantitative assessment of the transmission of macroeconomic policies.

The Great Financial Crisis and the ensuing Great Recession exposed several shortcomings of this modelling strategy (see, for instance, Lindé et al., 2016, and the MaRs Report, 2014). The most apparent limitation was the absence of a meaningful financial sector, which left models at a loss to explain the origins of the crisis and its consequences for the economy. Second, the prevailing models were built on a standard linear Gaussian set-up and were fine-tuned to analyse the impact of moderate shocks. The Great Financial Crisis was the most severe shock experienced by developed economies since the Great Depression and, as such, it represented a significant departure from the assumptions underlying these models. Third, models did not take into account the lower bound constraint on nominal interest rates, a constraint which started to bind just a few months after the beginning of the crisis. And, finally, the crisis brought to the forefront of the policy debate the importance of heterogeneity in the transmission of macroeconomic policies, both within and across economies.

\section{Absence of a Financial Sector}

Before the crisis, only a limited number of macroeconometric models used for policy purposes assigned a role to financial markets: among these, see in particular Christensen and Dib (2008), Christiano et al. (2004), and Dib et al. (2013). The crisis has revealed the relevance of the effects of financial shocks on the real economy and also the role of the financial system in propagating non-financial shocks. Del Negro et al. (2016), for example, show that DSGE models with financial frictions produce superior forecasts in periods of financial distress, although they do not perform as well in tranquil periods. In this respect, a prominent contribution is Christiano et al. (2014) who augment the standard monetary DSGE model to include a Bernanke-Gertler-Gilchrist financial accelerator mechanism

1. See, among others, the FRB-US and SIGMA models of the Federal Reserve Board, the NMCM, the NAWM and the EAGLE models of the European Central Bank, the GIMP of the IMF, the TOTEM model of the Bank of Canada, the QUEST model of the European Commission and the OECD fiscal of the Organisation for Economic Co-operation and Development. 
and idiosyncratic uncertainty faced by entrepreneurs about the outcome of their capital investments. The authors document that, contrary to more standard financial shocks, such as equity shocks, allowing the volatility of such cross-sectional idiosyncratic uncertainty to fluctuate over time captures the procyclical nature of credit. Other relevant extensions to incorporate financial frictions in macro models of the euro area include Queijo von Heideken (2009) and Lombardo and McAdam (2012).

The crisis however made it clear that incorporating financial frictions without explicitly modelling financial intermediaries meant that the models were unable to generate the adverse feedback loops between the financial system and the real economy that had been a prominent characteristic of the crisis. Gerali et al. (2010) represent one of the first attempts to introduce a banking sector into a quantitative DSGE model of the euro area with financial frictions. They find that the banking sector not only exacerbates the propagation of supply shocks, but also that shocks originating there can explain the bulk of the decline in euro area GDP in 2008. In addition, the destruction of bank capital has severe implications for investment and economic activity. Building on Gerali et al. (2010), Darracq Pariès et al. (2011) develop and estimate a model for the euro area where some firms are financially constrained and can only borrow by using revenue and capital as collateral. Households, in turn, borrow using housing and part of their wage income as collateral. In addition, the model features a bank capital channel and regulatory constraints. The estimated model allows for a structural interpretation of the real-financial feedback loops that were set in motion by the euro area crisis and highlights the role of bank risk aversion in amplifying a rise in corporate risk. Dedola et al. (2013), building on the seminal paper by Gertler and Karadi (2013), consider financial frictions in the form of balance sheet constraints on financial intermediaries to study the international dimension of unconventional policies in open economies. They find that with financial integration, unconventional policies in one country also benefit other countries and help stabilise financial and credit conditions globally. Fahr et al. (2013) quantify the effects of ECB interventions in mitigating the fall in economic activity and in dampening downside risks to price stability. ${ }^{2}$

\section{Non-linearity}

While standard linear models had proved useful for both forecasting and scenario analysis in "normal times", they quickly became unreliable for assessing the impact of economic and financial events of extreme magnitude, such as the increase in systemic risk and in the risk of secular stagnation and of sovereign default, as also noted by Hamilton (2016). In particular, both the Great Financial Crisis and the euro area crisis showed that the propagation of financial shocks can take place in a highly non-linear fashion when financial markets freeze and asset prices spiral downwards due to fire sales (Brunnermeier \& Pedersen, 2009; Caballero \& Simsek, 2013). The work by Boissay et al. (2016) takes an important step towards modelling the endogenous build-up and unravelling of credit imbalances. In their model, a credit boom may arise in response to a sequence of favourable conditions that push efficient banks, which finance productive 
projects to expand their corporate lending and amplify an economic boom. ${ }^{3}$ Similarly, macroprudential research agendas initiated after the crisis, such as the ECB's MaRs project ${ }^{4}$, also stressed the importance of including non-linearities and endogenous credit imbalances in macroeconomic models (see also Section 4). As documented by Hubrich and Tetlow (2015), among others, a non-linear framework is needed to properly assess the interaction of financial distress events with real economic activity, inflation and monetary policy.

\section{The Effective Lower Bound}

A large body of research has investigated the effects of economic policy when nominal policy rates are at their lower bound. Researchers generally find that the response of the economy to policy stimulus can be very different from in periods when nominal interest rates are expected to stay in positive territory (Christiano et al., 2011; Eggertsson, 2011; Woodford, 2011). Hence, the inclusion of an explicit effective lower bound on nominal interest rates, which effectively limits the ability of monetary policy to provide adequate stimulus to the economy using standard policy instruments, represents a key direction of development for models designed for forecasting and policy analysis. For example, Coenen and Warne (2014) use the ECB's New Area-Wide Model (NAWM; Christoffel et al., 2008) to analyse the evolution of the risks to price stability during the financial crisis. They show that the risk of deflation was amplified by the existence of the lower bound on nominal interest rates, which thus induced a noticeable downward bias in the risk balance, strengthening the case for unconventional policy measures to fill the resulting "policy gap" (Lindé et al., 2016; section 3 of this article; and Kilian \& Manganelli, 2008, for a formal measure of the balance of risks). Constraints arising from the effective lower bound have been compounded by a parallel gradual fall in the natural rate of interest in most developed economies, pushing central banks' policy rates down further. ${ }^{5}$

\section{Heterogeneity Across Countries and Economic Agents}

A very active line of research has focused on the relevance of heterogeneity among economic agents for the analysis of economic dynamics (Krusell \& Smith, 2006). Households may differ in their wealth but also in their patience (Carroll et al., 2015), employment status (Krusell et al., 2010) and productivity (Nakajima, 2012). Krueger et al. (2016), motivated by the US experience during the Great Recession of 2008-2009, show how wealth inequality can strongly amplify the effects of macroeconomic shocks. Using a DSGE model with household heterogeneity, Gornemann et al. (2016) conclude that "a monetary policy focused on unemployment stabilization helps "Main Street" by providing consumption insurance. It hurts "Wall Street" by reducing precautionary saving and, thus, asset prices."

3. Specifically, a moral hazard problem between among banks in the interbank funding market lies at the root of financial recessions As the economy slows, households start to save more and the interest rate declines, allowing also inefficient banks to borrow from the interbank market too. A crisis is triggered when the interest rate falls below a certain threshold and the share of inefficient banks borrowing in the interbank market becomes "too large". Since asymmetric information makes it difficult prevents to distinguish between good and bad banks, counterparty risk increases in the interbank market. As a result, the interbank market freezes, corporate credit collapses and the economy experiences a severe downturn.

4. The MaRs network was launched in spring 2010 by the European System of Central Banks, which consists of the 28 European Union (EU) national central banks and the ECB.

5. The natural rate of interest is the rate that is consistent with stable inflation and output (Wicksell, 1936), While it can be estimated in various different ways, there is broad agreement in the academic literature that it has declined over recent decades. Some estimates even suggest that the natural rate is currently negative in the euro area (Holston et al., 2016; Lemke \& Vladou, 2016), 
At a more aggregate level, the recent financial crisis also increased the need to understand how cross-country financial factors can affect macroeconomic performance. This is particularly important in a monetary union, such as the euro area, where heterogeneous cross-country conditions in financial markets and banking sectors have been a challenge for the single monetary policy. To address some of these issues, the ECB is currently developing a new multi-country macroeconometric model for the official projections of the five largest countries of the euro area (ECB-MC). The new model aims to provide a higher degree of granularity and a more explicit role for the financial sector, both of which are needed to achieve a more realistic modelling of the monetary policy transmission mechanism, beyond the standard channels. ${ }^{6}$ It does not however take into account household heterogeneity. Indeed, the vast majority of models - for reasons of tractability - continue to rely on a representative agent approach, thus leaving out key interactions among heterogeneous markets and agents. Policy models face a significant trade-off between enlarging the coverage, in terms of heterogeneity of agents/sectors/countries, and tractability. As a result, the distributional implications of changes in policy often remain neglected or highly stylised in policy models, a significant shortcoming at a time when inequality features prominently on the policy agenda in advanced economies.

The ECB, together with Eurosystem national central banks, has addressed this shortcoming by collecting household-level data on wealth and the structure of household portfolios in the euro area in the context of the Household Finance and Consumption Survey (HFCS). Besides documenting stylised facts about household portfolios, the HFCS has also been a valuable source of information about how household heterogeneity can affect the monetary transmission mechanism and for the calibration of economic models. For example, a key variable determining the strength of monetary transmission across countries is the marginal propensity to consume out of income (MPC), which can vary substantially depending on household characteristics, such as wealth (Carroll et al., 2014). In addition, the HFCS data have been used to estimate which wealthy households may behave as if they were credit constrained because they have substantial, but illiquid assets, the "wealthy hand-to-mouth" (Kaplan et al., 2014). Heterogeneous Agent New Keynesian (HANK) models can include a fraction of "wealthy hand-to-mouth" (Kaplan et al., 2016). When accounting for household heterogeneity in terms of wealth and liquidity, the intertemporal channel of monetary transmission (through the substitution effect) becomes less important than the income channel (through a general equilibrium increase in labour demand). Other examples where household heterogeneity can be relevant for monetary policy include the prevalence and distribution of fixed and adjustable-rate mortgages, credit-constrained households and leveraged households.

Moreover, recently the HFCS has also been used to assess the distributional impact of monetary policy (Draghi, 2016). For example, the two waves of the survey conducted so far, in 2010 and 2013, allow an assessment to be made of how net financial income has shifted between different households as interest rates have fallen, at least partly as a result of the loosening in the monetary policy stance. ${ }^{7}$ The results suggest that, for the euro area as a whole, although net

6. The development of a multi-country extension of the NAWM, named the Euro Area and Global Economy (EAGLE) model (Gomes et al., 2012), was also undertaken to tackle these issues. Bokan et al. (2016) document how the new financial and banking features of the EAGLE-FLI version of the model interact across countries and modify the transmission mechanism in the model.

7. In this period yields on two-year euro area benchmark bonds fell by 130 basis points and on ten-year bonds by 110 basis points. 
financial income as a fraction of total household income fell slightly, the position of those households with the lowest net wealth remained unchanged (since their debt payments were higher than their financial income), while the wealthiest households lost the most.

\section{Impact of Non-Standard Policy Measures}

Faced with the effective lower bound on policy rates, major central banks such as the US Federal Reserve System, the Bank of Japan, the Bank of England and the ECB took unprecedented action to mitigate downward pressures on economic activity and inflation. Some of the unconventional measures, such as large-scale asset purchase programmes, were widely used to address the lower bound constraint, while others, such as negative rates, long-term refinancing operations and targeted lending programmes, or a broadening of the collateral eligible for pledging against central bank refinancing, were more country-specific. The use of these unconventional policy measures has prompted considerable research efforts to study the effects of these new policies on asset prices, economic activity, and ultimately inflation. ${ }^{8}$

\section{Liquidity Provision}

Early in the crisis the ECB granted full and unlimited access to central bank liquidity, at a fixed rate and against adequate collateral, and offered a variety of long-term refinancing operations to counterparties. Garcia-de-Andoain et al. (2016) identify two main effects of central bank liquidity provision on interbank markets. First, central bank liquidity replaced the supply of liquidity in the (then frozen) interbank market during the Great Financial Crisis (2008-2010). Second, it increased the supply of liquidity in the interbank market in stressed countries (Greece, Italy and Spain) during the sovereign debt crisis (2011-2013). Research also found that weakly capitalized banks borrowed more from the central bank using riskier collateral than strongly capitalized banks. Weakly capitalized banks, in turn, bought the bonds of their, often stressed, sovereign (Drechsler et al., 2016). While fully consistent with a central bank's role as a lender of last resort (LOLR) that insures against systemic liquidity risk, these finding points to potential adverse side-effects for financial stability and, consequently, the need for strict banking supervision to accompany the LOLR function.

The use of micro-data was central to understanding the transmission mechanism of the ECB's liquidity policies. For example, Gambacorta and Marques (2011) illustrate that bank-specific characteristics, such as the amount of short-term funding, securitisation activities, the proportion of fee-based revenues and the capital position, can affect shifts in loan supply. Similarly, Altunbas et al. (2017) relate the systemic dimension of banks' risk to certain characteristics observed prior to the 2007-2009 crisis, such as strong credit growth and increasing reliance on wholesale funding. Stronger reliance on wholesale funding made banks more vulnerable to interbank market freezes and, hence, more likely to tap central bank facilities. Using information on banks' lending rates and their bidding behaviour in the two series

8. Krishnamurty and Vissing-Jorgensen (2011), Gagnon et al. (2011) and D'Amico and King (2012), for the US, and Joyce, Lasaosa et al. (2011), for the UK, investigated the impact of unconventional policies on asset prices while Gertler and Karadi (2013) and Del Negro et al. (2015) study the impact of the policies on the US economy. 
of targeted longer-term refinancing operations (TLTROs), ECB research (European Central Bank, 2016, box 3) shows that banks located in vulnerable countries that have participated in TLTROs have lowered their lending rates by more than non-participating banks. This has channeled the monetary stimulus to private-sector borrowers in the euro area who have been most in need of accommodation.

An alternative strategy to measuring the effects of liquidity policies, pioneered by Lenza, Pill and Reichlin (2010), makes use of standard vector autoregression (VAR) models. The analyses rely on different assumptions regarding how non-standard policy measures affect the real economy. They characterise the impact of the initial ECB liquidity policies through variations in money market spreads and the slope of the yield curve. Darracq Pariès and De Santis (2015), by contrast, study the ECB's three-year LTRO using the Bank Lending Survey (BLS). Ciccarelli et al. (2013), also using a VAR approach, document that the ECB's liquidity operations mitigated existing restrictions on private liquidity funding. All these studies point to positive macroeconomic effects of the non-standard measures adopted by the ECB in the first phase of the crisis. However, the results are affected by significant model and estimation uncertainty.

\section{Asset Purchases}

With the first Covered Bond Purchase Programme (CBPP), the ECB initiated a series of asset purchase programmes in 2009. Beirne et al. (2011) show that the CBPP was effective in pushing money market rates down and, more generally, easing the borrowing conditions of banks, firms and households, while, at the same time, improving liquidity in a segment of the financial market that saw spreads widening and liquidity deteriorating as the crisis progressed. During the most severe phase of the European sovereign debt crisis, the ECB supplemented the CBPP with the Securities Markets Programme (SMP) with a view to ensuring depth and liquidity in dysfunctional segments of the sovereign debt market. Several studies support the view that SMP purchases helped lower both yields and volatility, albeit sometimes only temporarily (Eser \& Schwaab, 2016; Ghysels et al., 2017). Carpenter et al. (2014) find evidence that both the ECB's liquidity policies and the SMP eased money market conditions in the euro area, resulting in an overall increase in bank lending. In August 2012, the ECB announced the Outright Monetary Transactions Programme (OMT), aimed at addressing the risk of self-fulfilling spikes in sovereign bond yields due to a perceived risk of euro area break-up, unrelated to economic and fiscal fundamentals. The OMT announcement had an immediate and strong effect on government bond yields although the programme was never activated. The sharp fall in yields in peripheral Member States, and the parallel rise in safe-haven bond yields like those on German Bunds, in the aftermath of the OMT announcement, is mostly associated with a repricing of the risk of currency redenomination (De Santis, 2015). The overall reduction in interest rates was particularly significant for Italy and Spain. Results from a multi-country VAR show that lower interest rates had overall positive effects on activity and prices in those countries (Altavilla et al., 2016).

While asset purchase programmes of the ECB up to mid-2014 were by and large motivated by the emergence and prevalence of considerable frictions in financial markets, the decision to launch the Public Sector Purchase Programme (PSPP) in January 2015 was taken against the background of a protracted period of low 
inflation and risks of a destabilisation of medium-term inflation expectations. Building on the seminal work by Vayanos and Vila (2009), whose framework of preferred-habitat investors creates scope for central bank asset purchases to affect asset prices, a growing body of the literature, using both event studies and time-series analysis, finds that the PSPP was effective in easing broad financial conditions and in stimulating the macroeconomy (Altavilla et al., 2015; Altavilla et al., 2016; Andrade et al., 2016; Blattner \& Joyce, 2016).

\section{Collateral Frameworks}

One important channel of transmission of central bank policies operates via the use of collateral in financial markets. Collateral gives lenders the opportunity to receive some payment in case of borrower default. Collateral can also improve borrower incentives to repay a loan (see for example Boot et al., 1991) or signal borrower ability to repay as in Bester (1985). It may, however, also reduce lender incentives to monitor and screen borrowers (Rajan \& Whinton, 1995) and create a false sense of security, while default risk remains, depending on the value of the assets used as collateral. Collateralised debt thus both lowers the information cost of borrowing and can become information-sensitive and create market instability in adverse states of the world, as pointed out by Gorton and Metrick (2012) and Holmström (2012; 2014).

Central banks change the mix of assets available for use by private market participants in two ways. First, through the collateral framework of their liquidity-providing operations, and second, through large-scale asset purchases, see e.g. Corradin et al. (2017). Changes in eligibility criteria and haircuts for collateral pledged in ECB refinancing operations impact the price of affected assets. Eligible assets, or asset with lower haircuts, are more valuable. For example, in conjunction with the move to the fixed-rate full-allotment regime, the ECB announced that it was possible to borrow against USD-denominated bonds subject to the requirement that the bonds are deposited in the European Economic Area. This change in the collateral framework increased the price of eligible USD bonds relative to ineligible but otherwise similar USD bonds (Corradin \& Rodriguez-Moreno, 2016). A similar effect is found when comparing bonds issued by sovereign agencies to those issued by the sovereign itself. Because the former are subject to a higher haircut at the ECB than the latter, even though they have identical risk, their price in the market is lower. Also, an important effect of the ECB's asset purchases under the SMP was to stabilise the value of the targeted government bonds, increasing their liquidity power when used as collateral.

At the same time, research also suggests that central bank bond purchases can also have unintended side effects for the collateral use of targeted bonds. Bond purchases decrease bond supply and can therefore increase bond specialness - the scarcity premium for procuring a bond in the repo market. For instance, Corradin and Maddaloni (2017) examine the Italian government bond market during SMP purchases. On the other hand, Aggarwal et al. (2017) show that central bank purchases of lower-quality bonds can mitigate disruptions in short-term funding markets because they reduce the lending fees for which low-quality collateral can be upgraded to high-quality collateral, which is in high demand in the private market when there is stress in the financial system (as measured by 
the Composite Indicator of Systemic Stress, CISS, see Holló et al., 2012). Good collateral assets are necessarily scarce and, hence, requiring collateral for financial transactions may lead to considerable distortions in the pricing of financial assets. For example, it may lead to volatility in secured markets and a decoupling of secured and unsecured bond prices when credit risk leads agents to hold more secured bonds (Heider \& Hoerova, 2009). The main lesson from this strand of research is that collateralised lending can address moral hazard and asymmetric-information problems in financial markets, but can create its own financial stability issues, consistent with the findings of Holmström and Gorton and Metrick. This also echoes concerns expressed by regulators on risks in securities lending and repos (see e.g. Bank for International Settlements, 2015; Financial Stability Board, 2013).

\section{Negative Interest Rates}

Several central banks around the world (e.g. in Denmark, Switzerland, Sweden and Japan) have set negative interest rates as a measure to further stimulate economic activity, to empower other policy measures, such as asset purchases, or, in the case of small open economies, to stabilise their currencies. The ECB took that step for the first time in June 2014 and has since then set the rate it pays banks for their deposits at $-0.4 \%$. The breach of the zero-lower bound naturally raised the question of whether negative rates would be transmitted differently through financial markets and whether cash substitution effects would kick in.

This has led to a further refinement of the lower bound terminology. As Cœuré (2016) illustrated, the "physical lower bound" for nominal interest rates is determined by the materialisation of disintermediation risks, i.e. when the opportunity cost of holding money falls below the cost of holding assets with negative yields. The "economic lower bound", by contrast, is determined by a situation in which further rate cuts would either have no effect or would actually have adverse effects on aggregate economic activity. This might happen when bank profitability falls, e.g. through the impact on net interest margins or the reluctance of banks to charge negative rates on retail deposits (see Heider et al., 2017), so that capital generation via retained earnings is reduced and eventually lending is restricted due insufficient capital accumulation (see e.g. Bernanke \& Reinhart, 2004), or the recent concept of a "reversal rate" by Brunnermeier and Koby (2017).

In addition, challenges for financial stability may arise if negative rates prompt banks to increase their exposure to lower quality credit portfolios and thus lead to excessive risk-taking by banks. This happens if banks are financing risky loans with negative net present value (Dell'Ariccia et al., 2014). Indeed, Heider et al. (2017) show that under negative policy rates banks with higher deposit ratios concentrate their lending on riskier firms in the market. However, possible adverse effects on financial stability are related to banks' business models and can be mitigated by more stringent prudential supervisory activity. Furthermore, the risk taking of high-deposit banks is concentrated in banks that have comparatively low equity holdings.

The exact magnitude of the effect of negative interest rates on aggregate bank profitability is uncertain, as the relevant policy counterfactual of a non-accommodative monetary policy is missing. Recent empirical evidence (International 
Monetary Fund, 2017; Rostagno et al., 2016) shows, however, that the overall impact on bank profitability of negative interest rates is positive, in particular in the short term, as low and negative interest rates, as long as they are still above the economic lower bound, tend to induce an increase in asset prices and therefore higher collateral values (Carpenter et al., 2013; Demiralp et al., 2017). Moreover, through its general equilibrium effects, accommodative monetary policy has an overall positive impact on the financial position of borrowers. Recent research by Beck et al. (2013) shows, for instance, a negative relationship between economic growth and non-performing loans.

Constraints arising from the effective lower bound have also been alleviated by the introduction of forward guidance, i.e. communication by the central bank about its reaction function and its expectations about the future course of the economy (see Cœuré, 2017, for a discussion). Standard DSGE models tend to overestimate the impact of forward guidance on the economy, a phenomenon known as the "forward guidance puzzle" (Del Negro et al., 2015). Some explanations of the puzzle have been provided which depart from the rational expectation paradigm and assume bounded rationality making economic agents partially myopic (Gabaix, 2015; García-Schmidt \& Woodford, 2015).

\section{New Prudential Frameworks}

The euro area crisis was characterised by the dynamics of the sovereign-bank nexus and mutually reinforcing contagion effects: rising sovereign default risks had negative effects on bank capital through, for example, higher funding costs and increasing liquidity and solvency risks, while bank solvency risks in turn amplified sovereign default risks through bail-out pressure (see e.g. Cooper and Nikolov, 2015, for a theoretical model and Alter \& Beyer, 2014, for an empirical analysis). During the sovereign debt turmoil the market for high-quality collateral, mainly in the form of government bonds, became increasingly segmented along national borders. Domestic banks in fiscally stressed countries increased their holdings of domestic sovereign bonds considerably (Ongena et al., 2016; Colangelo et al. 2017). These findings have confirmed the need to break the doom loop between banks and sovereigns and to put in place homogeneous financial and regulatory rules (Colliard, 2015), and have thus vindicated the decision in 2012 to create a Single Supervisory Mechanism (SSM) for 19 euro area countries.

\section{Policy Interaction, Transmission and Potential Conflicts between Monetary and Prudential Policies}

With the setting up of the SSM in November 2014, the ECB has been tasked with two more policy functions, beyond the central bank's traditional monetary policy role, namely micro- and (together with national competent authorities) macroprudential policy. Microprudential policy ensures the soundness of individual financial institutions while macroprudential policy aimes at safeguarding the stability of the financial system as a whole (Hanson et al., 2011). The SSM was established on the basis of the principle of separation of monetary and prudential policy, and central bankers generally consider that sound banking and price stability are mutually reinforcing objectives (Cœuré, 2013). It is nevertheless useful for research to explore further the interaction of microprudential, 
macroprudential and monetary policies. Beyer et al. (2017), for example, illustrate that in an economic environment characterised by low interest rates, low inflation and low economic growth, microprudential policy has a preference for tightening capital requirements in order to increase banks' resilience to adverse shocks. A preference for tighter capital requirements is reinforced by the literature on the "risk taking channel" of banks that shows that low profitability and lower interest rates provide incentives for banks to take on more risk by increasing maturity transformation and investing in riskier assets (see e.g. Dell'Ariccia et al., 2016; Maddaloni \& Peydro, 2013). ${ }^{9}$ In the short run, tighter micro-prudential policies may weight on bank lending and, to this extent, play a procyclical role. Macroprudential policy, in contrast, is clearly counter-cyclical, for example by releasing countercyclical capital buffers in order to mitigate contagion and spill-over effects. However, an accommodative monetary policy can mitigate the short-run costs of an increase in capital requirements, especially at the lower bound of interest rates (Mendicino et al., 2017; Beyer et al., 2017).

\section{Impact Analyses of Prudential Policies}

Significant research efforts have been devoted to developing general equilibrium models that help to shed light on the links between financial intermediation and the economy and, eventually, the channels of transmission of macroprudential policies. In the European System of Central Banks (ESCB), macroeconomic modelling efforts initiated under the macroprudential research network (MaRs) have led to the development of a (new) macroprudential framework for policy analysis. The 3D model of Clerc et al. (2015) is the result of a collective ESCB effort to design a decision-support tool for valuable feedback to policymakers on capital regulatory policy (MaRS Report, 2014; Clerc et al., 2015; Mendicino et al., 2016).Contrary to previous models, it includes default risk not only for non-financial firms and households but also for banks (hence " $3 \mathrm{D}$ "). ${ }^{10} \mathrm{~A}$ distinctive feature of the model is that it provides a rationale for capital regulation as a welfare improving response to two types of distortions: limited liability of banks and bank funding cost externalities. Both distortions lead to excessive risk taking by banks. Capital requirements align private and social risk-taking incentives and can be beneficial for welfare.

A transmission channel that is of particular importance when analysing the impact of regulatory policy on bank behaviour is the bank capital channel (see Boivin et al., 2010, and the discussion in Heider et al., 2017). There exists broad evidence that banks that are operating closer to capital constraints react more strongly, in terms of their lending supply, when they are exposed to changes in their capital (either a required increase in capital or expected loss of market value). The more banks are leveraged, the more sensitive is their loan supply reaction to tighter capital requirements. Empirical studies based on Italian and US data find that the impact of changes in monetary policy rates on poorly capitalised banks is significantly larger (Gambacorta \& Mistrulli, 2004; Kishan \& Opiela, 2006; Van den Heuvel, 2007; 2012). Maddaloni and Peydro (2013) provide further evidence

9. This might be even further exacerbated if banks face restrictions imposed by institutional or regulatory constraints that require the achievement of nominal targets for banks' returns.

10. The 3D model was recently operationalized to all SSM countries and it is now part of the macro-prudential toolkit of the ECB and the euro area macro-prudential policy authorities. The operationalization of the 3D model occurred under the Task Force on Operationalization of Macroprudential Research (OMRTF). The aim was to provide a common tool to all SSM countries for macro-prudential policy analysis. For further details, see OMRTF Report (2017) and Mendicino et al. (2016). 
that euro area banks with a stronger capital position were able to ease lending conditions more during the crisis than banks with higher capital constraints.

Another different set of regulatory instruments are requirements for liquidity or liquidity buffers (see e.g. Bank for International Settlements, 2010, 2015) for detailed discussions and analyses). Micro- and macroprudential liquidity instruments, such as the Liquidity Coverage Ratio (LCR) and the Net Stable Funding Ratio (NSFR), have a direct impact on banks' funding needs and composition. As a result, increasing funding costs might be passed on and transmitted to credit supply conditions. Empirical evidence for the euro area is, however, still scarce as these instruments are either only currently being phased in (LCR not fully until 2019) or will only be in place from 2018 onwards (NSFR) (see, however, the recent cost-benefit analysis of liquidity regulation by Hoerova et al., 2017). Evidence for the US suggests that more liquid and longer-term funded banks might respond less strongly to monetary policy actions (see, for example, Kashyap and Stein (2000) who report that monetary policy has a greater impact on banks with lower liquidity buffers).

To conclude, evidence suggests that coordination between microprudential and macroprudential policies is critical to assess the appropriate adjustment of capital and liquidity buffers according to the cycle (see e.g. Angelini et al., 2012). While there are valuable benefits to be gained from information-sharing between microprudential supervision and monetary policy making, the "separation principle" applied to these two functions ensures that the decision-making responsibilities of these two areas remain distinct.

The Great Financial Crisis and the euro area crisis have profoundly challenged economic thinking and modelling and have led to a redirection of economic research both in academia and at central banks. This change in the direction of travel was needed to support policymakers in their effort to remain faithful to their mandate amid daunting and unprecedented challenges. New ways of thinking and innovative modelling approaches were required to design, calibrate and monitor the effects and effectiveness of non-standard measures, such as asset purchases, forward guidance, liquidity operations and negative interest rates. In particular, new macroeconomic models have been and are being developed that give more importance to financial markets and heterogeneity across countries, firms and households. The analysis of interlinked bank-level, firm-level and household-level data have supported this effort. Moreover, remarkable progress has been made in analysing prudential and regulatory policies and their interaction with monetary policies (in particular when employing non-standard measures).

This foreword suggests that research in both academia and in central banks is now arguably in a better position to support policymakers in their quest to fulfil their mandates than a few years ago. However, knowledge gaps remain. On the modelling side, with the likelihood of hitting the effective lower bound having increased noticeably on the back of the fall in real natural interest rates, more 
efforts need to be undertaken to incorporate unconventional policy measures and non-linearity in the transmission of shocks into mainstream macroeconomic models. What might be unconventional today might well become conventional in the future. This requires, among other things, to complement the current dominant use of $a d-h o c$ event studies, which fail to capture the persistence of central bank actions, to quantify the impact of such measures on both asset prices and the broader macroeconomy. Considerable knowledge gaps also remain with respect to the transmission of negative rates, and their financial stability repercussions, calling for a more explicit treatment of the role of bank profits in determining bank lending decisions and, ultimately, macroeconomic outcomes. Advances in this direction should also help improve further our understanding of how regulatory actions affect financial markets and banks in their intermediation capacity. Introducing elements of bounded rationality can help understand better the impact of central bank communication and in particular of forward guidance. Further progress is also warranted when it comes to incorporating nonlinearity in the transmission of shocks. Finally, given the relevance of heterogeneity for the transmission of monetary policy and the rising importance of inequality in the broader policy discussion, central banks need to understand better the distributional consequences of their measures. For this, we need models with more heterogeneous agents. A continuation of the current research efforts is therefore required.

With that in mind, theoretical and empirical models will continue to fulfil their role of clarifying the assumptions on which policy recommendations rest, allowing for general equilibrium analysis, and disciplining the policy making process (Couré, 2012). As General Eisenhower once said: "In preparing for battle I have always found that plans are useless, but planning is indispensable". So, when preparing for the next crisis, we should be conscious that models will prove useless again at times, but that modelling will nevertheless remain indispensable.

\section{BIBLIOGRAPHY}

Aggarwal, R., Bai, J. \& Laeven, L. (2017). The Role of the Government Bond Lending Market in Collateral Transformation. Georgetown McDonough School of Business, Research Paper $\mathrm{N}^{\circ} 269251$.

Altavilla, C., Carboni, G. \& Motto, R. (2015). Asset purchase programmes \& financial markets: lessons from the euro area. European Central Bank, Working Paper $\mathrm{N}^{\circ} 1864$.

Altavilla, C., Giannone D. \& Lenza, M. (2016). The Financial \& Macroeconomic Effects of the OMT Announcements. International Journal of Central Banking, 12(3), 29-57, September.

Alter, A. \& Beyer, A. (2014). The Dynamics of Spillover Effects During the European Sovereign Debt Crisis. Journal of Banking \& Finance, 42(1), 134-153.

Altunbas, Y., Manganelli S. \& Marques-Ibanez, D. (2015). Realized Bank Risk during the Great Recession. Board of Governors of the Federal Reserve System, International Finance Discussion Papers $\mathrm{N}^{\circ} 1140$.

Andrade, P., Breckenfelder, J., De Fiore, F., Karadi P. \& Tristani, O. (2016). The ECB's asset purchase programme: an early assessment. European Central Bank, Working Paper $\mathrm{N}^{\circ} 1956$. 
Angelini, P., Nicoletti-Altimari, S. \& Visco, I. (2012). Macroprudential, Microprudential \& Monetary Policies: Conflicts, Complementarities \& Trade-offs. Banca d'Italia, Occasional Paper $\mathrm{N}^{\circ} 140$.

Ball, L. \& Mazumder, S. (2011). Inflation dynamics \& the great recession. Brookings Papers on Economic Activity, Vol. 42, 1 (Spring), 337-405.

Bank for International Settlements (2010). ‘An Assessment of the Long-Term Economic Impact of Stronger Capital \& Liquidity Requirements', Basel Committee on Banking Supervision.

Bank for International Settlements (2015). Central bank operating frameworks \& collateral markets. Committee on the Global Financial System Markets Committee, CGFS Paper $\mathrm{N}^{\circ} 53$.

Bank for International Settlements (2015). 'Regulatory Change \& Monetary Policy', Committee on the Global Financial System Markets Committee, CGFS Paper $\mathrm{N}^{\circ} 54$.

Beck, R., Jakubik, P. \& Piloiu, A. (2013). Non-performing loans: What matters in addition to the economic cycle? European Central Bank, Working Paper $\mathrm{N}^{\circ} 1515$.

Beirne, J., Dalitz, L., Ejsing, J., Grothe, M., Manganelli, S., Monar, F., Sahel, B., Sušec, M., Tapking, J. \& Vong, T. (2011). The impact of the Eurosystem's covered bond purchase programme on the primary \& secondary markets. European Central Bank, Occasional Paper $\mathrm{N}^{\circ} 122$.

Bernanke, B. \& Reinhart, V. (2004). Conducting Monetary policy at Very Low Short-Term Interest Rates. American Economic Association Papers \& Proceedings, Vol. 94 (2), 85-90.

Bester, H. (1985). Screening vs. Rationing in Credit Markets with Imperfect Information. American Economic Review, 75, 850-855.

Beyer, A., Nicoletti, G., Papadopoulou, N., Papsdorf, P., Rünstler, G., Schwarz, C. Sousa, J. \& Vergote, O. (2017). The Transmission Channels of Monetary, Macro- \& Microprudential Policies \& their Interactions, European Central Bank, Occasional Paper $\mathrm{N}^{\circ} 191$.

Blattner, T.S \& Joyce, M. (2016). Net debt supply shocks in the euro area \& the implications for QE. European Central Bank, Working Paper N 1957.

Boissay, F., Collard, F. \& Smets; F. (2016). Booms \& Banking Crises. Journal of Political Economy, 124(2). 489-538.

Boivin, J., Kiley, M., \& Mishkin, F.S. (2010). How Has the Monetary Transmission Mechanism Evolved over Time? In B. M. Friedman, \& M. Woodford (Ed.). Handbook of Monetary Economics, 369-422. New-York: Elsevier.

Boot, A., Thakor, A. \& Udell, G. (1991). Secured Lending \& Default Risk: Equilibrium Analysis, Policy Implications \& Empirical Results. Economic Journal, 101, 458-472.

Brunnermeier M.K. \& Koby, Y. (2016). The Reversal Rate: Effective Lower Bound on Monetary Policy. Princeton University.

Brunnermeier, M.K. \& Pedersen, L.H. (2009). Market Liquidity \& Funding Liquidity. Review of Financial Studies, 22(6), 2201-2238.

Caballero, R.J. \& Simsek, A. (2013). Fire Sales in a Model of Complexity. Journal of Finance, 68(6), 2549-2587.

Carpenter, S., Demiralp, S. \& Eisenschmidt, J. (2013). The effectiveness of the non-standard policy measures during the financial crises: the experiences of the Federal Reserve \& the European Central Bank. European Central Bank, Working Paper $\mathrm{N}^{\circ} 1562$. 
Carroll, C. D., Slacalek, J. \& Tokuoka, K. (2014). The Distribution of Wealth and the MPC: Implications of New European Data. American Economic Review Papers \& Proceedings, 104(5), $107-111$.

Christensen, I. \& Dib, A. (2008). The financial accelerator in an estimated New Keynesian model. Review of Economic Dynamics, 11(1), 155-178.

Christiano, L., Eichenbaum, M. \& Evans, C.L. (2005). Nominal Rigidities \& the Dynamic Effects of a Shock to Monetary Policy. Journal of Political Economy, 113(1). 1-45.

Christiano, L., Eichenbaum, M. \& Rebelo, S. (2011). When Is the Government Spending Multiplier Large? Journal of Political Economy, 119(1), 78-121.

Christiano, L., Motto, R. \& Rostagno, M. (2004). The Great Depression \& the Friedman-Schwartz Hypothesis, NBER, Working Papers $N^{\circ} 10255$.

Christiano, L., Motto, R. \& Rostagno, M. (2014). Risk Shocks, American Economic Review, 104(1), 27-65.

Christoffel, K. \& Coenen, G. (2008). The new area-wide model of the euro area: a micro-founded open-economy model for forecasting \& policy analysis. European Central Bank, Working Paper $\mathrm{N}^{\circ} 944$.

Ciccarelli, M., Maddaloni, A. \& Peydro, J.L. (2013). Heterogeneous transmission mechanism: monetary policy \& financial fragility in the Eurozone. Economic Policy, 28(75), 459-512.

Ciccarelli, M. \& Osbat, C. (Ed.) (2017). Low inflation in the Euro Area: Causes \& Consequences. European Central Bank, Occasional Paper $\mathrm{N}^{\circ} 181$.

Clerc L., Derviz, A., Mendicino, C., Moyen, S., Nikolov, K., Stracca, L., Suarez, J. \& Vardoulakis, A.P. (2015). Capital Regulation in a Macroeconomic Model with Three Layers of Default, European Central Bank, Working Paper $\mathrm{N}^{\circ} 1827$.

Coenen, G. \& A. Warne (2014). Risks to Price Stability, the Zero Lower Bound, and Forward Guidance: A Real-Time Assessment. International Journal of Central Banking, 10(2), 7-54.

Cœuré, B. (2012). Which models do we need in times of crisis? International Conference on Macroeconomic Modelling in Times of Crisis, Banque de France, CEPREMAP, Federal Reserve Bank of Atlanta \& Centre d'Analyse Stratégique, Paris, 26 October.

Cœuré, B. (2013). Monetary Policy \& Banking Supervision. Central Banking: Where Are We Headed? Symposium in honour of Stefan Gerlach's contribution to the Institute for Monetary \& Financial Stability, Goethe University, Frankfurt-am-Main, 7 February.

Cœuré, B. (2016). Assessing the implications of negative interest rates. Yale Financial Crisis Forum, Yale School of Management, New Haven, 28 July.

Cœuré, B. (2017). Central bank communication in a low interest rate environment. Open Economies Review, forthcoming.

Colangelo, A., Giannone, D., Lenza, M., Pill, H. \& Reichlin, L. (2017). The national segmentation of euro area bank balance sheets during the financial crisis. Empirical Economics, 53(1), $247-265$.

Colliard, J.E. (2015). Optimal supervisory architecture \& financial integration in a banking union, European Central Bank, Working Paper № 1786.

Cooper, R. \& Nikolov, K. (2015). Government Debt \& Banking Fragility: The Spreading of Strategic Uncertainty. National Bureau of Economic Research, Working Paper N$^{\circ} 19278$. 
Corradin, S., Heider, F. \& Hoerova, M. (2017). On collateral: Implications for financial stability $\&$ monetary policy. European Central Bank.

Corradin, S. \& Maddaloni, A. (2017). The Importance of Being Special: Repo Markets during the Crisis, European Central Bank, Working Paper $\mathrm{N}^{\circ} 2065$.

Corradin, S. \& Rodriguez-Moreno, M. (2016). Violating the Law of One Price: The Role of Non-Conventional Monetary Policy. European Central Bank, Working Paper № 1927.

D’Amico, S. \& King, T.B. (2013). Flow \& Stock Effects of Large-Scale Treasury Purchases: Evidence on the Importance of Local Supply. Journal of Financial Economics, 108 (2), 425-448.

Darracq Pariès, M. \& De Santis, R. (2015). A non-standard monetary policy shock: The ECB's 3-year LTROs \& the shift in credit supply. Journal of International Money \& Finance, 54, 1-34.

Darracq Pariès, M., Kok, C. \& Rodriguez-Palenzuela, D. (2011). Macroeconomic propagation under different regulatory regimes: evidence from an estimated DSGE model for the euro area. International Journal of Central Banking, 7(4), 49-113.

Dedola, L., Karadi, P., \& Lombardo, G. (2013). Global implications of national unconventional policies. Journal of Monetary Economics, 60(1). 66-85.

Dell'Ariccia G., Laeven, L. \& Marquez, R. (2014). Real interest rates, leverage, \& bank risk-taking, Journal of Economic Theory, 149, 65-99.

Dell'Ariccia, G. L. Laeven \& G. Suarez (2016). Bank leverage \& monetary policy's risk-taking channel: Evidence from the United States, European Central Bank, Working Paper N 1903.

Del Negro, M., Giannoni, M \& C. Patterson (2015). The Forward Guidance Puzzle. Federal Reserve Bank of New York, Staff Report N ${ }^{\circ} 574$.

Del Negro, M., Hasegawa, R.B. \& Schorfheide, F. (2016). Dynamic prediction pools: An investigation of financial frictions \& forecasting performance. Journal of Econometrics, 192(2), 391-405.

Demiralp, S., Eisenschmidt, J. \& Vlassopoulos, T. (2017). Negative interest rates, excess liquidity \& bank business models: Banks' reaction to unconventional monetary policy in the euro area.

De Santis, R. (2015). A measure of redenomination risk. European Central Bank, Working Paper $\mathrm{N}^{\circ} 1785$.

Dib, A., Mendicino, C. \& Zhang Y. (2013). Price-level targeting rules \& financial shocks: The case of Canada. Economic Modelling, 30, 941-953.

Draghi, M. (2016). Stability, equity \& monetary policy. 2nd DIW Europe Lecture, German Institute for Economic Research (DIW), Berlin, 25 October.

Drechsler, I., Drechsel, T., Marques-Ibanez, D. \& Schnabl P. (2016). Who Borrows from the Lender of Last Resort? Journal of Finance, forthcoming.

Eggertsson, G.B. (2011). What fiscal policy is effective at zero interest rates? In: NBER Macroeconomics Annual 2010, pp. 59-112.

Eser, F. \& Schwaab, B. (2016). Evaluating the impact of unconventional monetary policy measures: Empirical evidence from the ECB's Securities Markets Programme. Journal of Financial Economics, 119, 147-167.

European Central Bank (2016). The Second Series of Targeted Longer-Term Refinancing Operations (TLTRO II). Economic Bulletin, 3. 
Fahr, S., Motto, R. Rostagno, M., Smets, F. \& Tristani, O. (2013). A monetary policy strategy in good \& bad times: lessons from the recent past. Economic Policy, 28(74), 243-288.

Financial Stability Board (2013). Policy Framework for Addressing Shadow Banking Risks in Securities Lending \& Repos.

Gabaix, X. (2016). A Behavioral New-Keynesian Model, National Bureau of Economic Research, Working Paper $\mathrm{N}^{\circ} 22954$.

Gagnon, J., Raskin, M., Remache, J. \& Sack, B., (2011). The Financial Market Effects of the Federal Reserve's Large-Scale Asset Purchases. International Journal of Central Banking, 7 (1), 3-43.

Gambacorta, L. \& Marques Ibanez, D. (2011). The bank lending channel: lessons from the crisis. Economic Policy, 26(66), 135-182.

Gambacorta, L. \& Mistrulli, P.E. (2004). Does Bank Capital Affect Lending Behavior? Journal of Financial Intermediation, 13, 436-457.

Garcia-de-Andoain, C., Heider, F., Hoerova, M. \& Manganelli, S. (2016). Lending-of-last-resort is as lending-of-last-resort does: Central bank liquidity provision and interbank market functioning in the euro area. Journal of Financial Intermediation, 28, 32-47.

García-Schmidt, M. \& Woodford, M. (2015). Are Low Interest Rates Deflationary? A Paradox of Perfect-Foresight Analysis. National Bureau of Economic Research, Working Paper $\mathrm{N}^{\circ} 21614$.

Gerali, A., Neri, S., Sessa, L., Signoretti, F.M. (2010). Credit \& Banking in a DSGE Model of the Euro Area. Journal of Money, Credit \& Banking, 42(s1), 107-141.

Gertler, M \& Karadi, P. (2013). QE 1 vs. 2 vs. 3. A Framework for Analyzing Large-Scale Asset Purchases as a Monetary Policy Tool. International Journal of Central Banking, 9(1), 5-53.

Ghysels, E., Manganelli, S., Idier, J. \& Vergote, O. (2017). A high frequency assessment of the ECB Securities Markets Programme. Journal of the European Economic Association, 15, $218-243$.

Gomes, S., Jacquinot, P. \& M. Pisani, M. (2012). The EAGLE. A model for policy analysis of macroeconomic interdependence in the euro area. Economic Modelling, 29(5), 1686-1714.

Gornemann, N., Kuester, K. \& Nakajima, M. (2016). Doves for the Rich, Hawks for the Poor? Distributional Consequences of Monetary Policy. Board of Governors of the Federal Reserve System, International Finance Discussion Paper $\mathrm{N}^{\circ} 1167$.

Gorton, G. \& Metrick, A. (2012). Securitized banking \& the run on repo. Journal of Financial Economics, 104(3), 425-451.

Hamilton, J.D (2016). Macroeconomic Regimes \& Regime Shifts. In: J. Taylor \& H. Uhlig (Eds.). Handbook of Macroeconomics, Volume 2, pp. 163-201. Elsevier.

Hanson, S., Kashyap, A. \& Stein, J.C. (2011). A macroprudential approach to financial regulation. Journal of Economic Perspectives, 25(1), 3-28.

Heider, F. \& Hoerova, M. (2009). Interbank lending, credit risk premia, and collateral. International Journal of Central Banking, 5, 1-39.

Heider, F. Saidi, F. \& Schepens, G. (2017). Life Below Zero: Bank Lending Under Negative Policy Rates European Central Bank, unpublished manuscript.

Hoerova, M., Mendicino, C., Nikolov, K., Schepens, G. \& Van den Heuvel, S. (2017). Benefits \& Costs of Liquidity Regulation: Empirical Evidence and Quantitative Evaluation. European Central Bank. 
Holló, D., Kremer, M. \& Lo Duca, M. (2012). CISS - A composite indicator of systemic stress in the financial system. European Central Bank, Working Paper $\mathrm{N}^{\circ} 1426$.

Holmström, B. (2012). The Nature of Liquidity Provision: When Ignorance is Bliss. Presidential Address, Econometric Society, Chicago.

Holmström, B. (2014). Understanding the role of debt in the financial system. Bank for International Settlements, Working Paper $\mathrm{N}^{\circ} 479$.

Holston, K, Laubach, T. \& Williams J.C. (2016). Measuring the Natural Rate of Interest: International Trends \& Determinants. Federal Reserve Bank of San Francisco, Working Paper $\mathrm{N}^{\circ} 2016-11$

Hubrich, K. \& Tetlow, R.J. (2015). Financial stress and economic dynamics: The transmission of crises. Journal of Monetary Economics, 70(C), 100-115.

International Monetary Fund (2017). Negative Interest Rate Policies - Initial Experiences and Assessments. Policy Papers, 3 August.

Joyce, M., Lasaosa, A., Stevens, I. \& Tong, M. (2011). The Financial Market Impact of Quantitative Easing in the United Kingdom. International Journal of Central Banking, 7(3), 113-161.

Kaplan, G., Violante, G. \& Weidner, J. (2014). The Wealthy Hand-to-Mouth. Brookings Papers on Economic Activity Spring 2014, 77-144.

Kaplan, G., Moll, B. \& Violante, G. (2016). Monetary policy according to HANK. European Central Bank, Working Paper $\mathrm{N}^{\circ} 1899$.

Kilian, L. \& Manganelli, S. (2008). The Central Banker as a Risk Manager: Estimating the Federal Reserve's Preferences under Greenspan. Journal of Money, Credit and Banking, 40(6), 1103-1129.

Kishan, R. \& Opiela, T. (2006). 'Bank Capital \& Loan Asymmetry in the Transmission of Monetary Policy', Journal of Banking \& Finance, 30, 259-285.

Krishnamurthy, A., \& Vissing-Jorgensen, A. (2011). The Effects of Quantitative Easing on Long-term Interest Rates. Brookings Papers on Economic Activity Fall 2011, 215-265.

Krueger, D., Mitman, K. \& Perri, F. (2016). Macroeconomics \& Household Heterogeneity. In: J. Taylor \& H. Uhlig (Eds.). Handbook of Macroeconomics, Volume 2, pp. 843-921, Elsevier.

Krusell, P. \& Smith, A. (2006). Quantitative macroeconomic models with heterogeneous agents. In R. Blundell, W. Newey \& T. Persson (Eds.). Advances in Economics \& Econometrics: Theory \& Applications, Ninth World Congress, Econometric Society Monographs, pp. 298-340, Cambridge University Press.

Krusell, P., Sahin, A. \& Mukoyama, T. (2010). Labour-Market Matching with Precautionary Savings and Aggregate Fluctuations. Review of Economic Studies, 77 (4), 1477-1507.

Kuttner, K. \& Robinson, T. (2010). Understanding the flattening Phillips curve. North American Journal of Economics \& Finance. Special Issue: 50 Years of the Phillips Curve, 21, 110-125.

Lemke, W. \& Vladu, A. (2016). Below the zero lower bound - a shadow-rate term structure model for the euro area. Deutsche Bundesbank, Discussion Paper $\mathrm{N}^{\circ} 32-2016$.

Lenza, M., Pill, H. \& Reichlin, L. (2010). Monetary policy in exceptional times. Economic Policy, 25, 295-339.

Lindé, J., Smets, F. \& Wouters, R. (2016). Challenges for Central Banks' Macro Models. Centre for Economic Policy Research, Discussion Paper $\mathrm{N}^{\circ} 11405$. 
Lombardo, G. \& McAdam, P. (2012). Financial market frictions in a model of the Euro area. Economic Modelling, 29(6). 2460-2485.

Maddaloni, A. \& Peydro, J.L. (2013). Monetary Policy: Macroprudential Policy \& Banking Stability: Evidence from the Euro Area, International Journal of Banking, 9(1), 121-169.

MaRs Report (2014). Report on the Macroprudential Research Network (MaRs). European Central Bank.

Mendicino, C., Nikolov, K., Suarez, J. \& Supera, D. (2016). Optimal Dynamic Capital Requirements. CEMFI, Working Paper $\mathrm{N}^{\circ} 1614$.

Mendicino, C., Nikolov, K., Suarez, J. \& Supera, D. (2017). Bank Capital in the Short and in the Long Run. Second Annual ECB Macroprudential Policy and Research Conference, European Central Bank, 11-12 May.

Nakajima, M. (2012). Business Cycles in the Equilibrium Model of Labor Market Search and Self-insurance. International Economic Review, 53(2), 399-432.

Ongena, S., Popov, A. \& Van Horen, N. (2016). The invisible hand of the government: Moral suasion. during the European sovereign debt crisis. European Central Bank, Working Paper $\mathrm{N}^{\circ} 1937$.

Queijo von Heideken, V. (2009). How Important are Financial Frictions in the United States \& the Euro Area? Scandinavian Journal of Economics, 111(3), 567-596.

Rajan, R. \& Winton, A. (1995). Covenants and collateral as incentives to monitor. Journal of Finance, 50, 1113-1146.

Rostagno, M, Bindseil, U., Kamps, A., Lemke, W., Sugo, T. \& Vlassopoulos, T. (2016). Breaking through the zero line: The ECB's Negative Interest Rate Policy. Negative interest rates: lessons learnt ... so far. Brookings Institution, Washington DC, 6 June.

Smets, F. \& Wouters, R. (2007). Shocks \& Frictions in US Business Cycles: A Bayesian DSGE Approach. American Economic Review, 97(3), 586-606.

Van den Heuvel, S. (2007). Do Monetary Policy Effects on Bank Lending Depend on Bank Capitalization? University of Pennsylvania Working Paper.

Van den Heuvel, S. (2012). Banking Conditions and the Effects of Monetary Policy: Evidence from U.S. States, B.E. Journal of Macroeconomics (Online), 12(2).

Vayanos, D. \& Vila, J (2009). A Preferred-Habitat Model of the Term Structure of Interest Rates, NBER Working Paper $\mathrm{N}^{\circ} 15487$.

Wicksell, K. (1936). Interest \& Prices. London: Royal Economic Society.

Woodford, M. (2011). Simple Analytics of the Government Expenditure Multiplier. American Economic Journal: Macroeconomics, 3(1), 1-35. 